all the havoc wrought by cancer. Should this be correct, what scientific value, if any, would attach to the strictures in your leading article? Were the researches of Petry and of Hartog (which I meant to do myself) "wild speculation"? If a malignant tumour possess an enzyme totally different from that widely present in traces in normal tissues, is not that a fact of supreme significance and import? I ask your readers to judge my work for themselves. Its chief conclusions have been advanced in Liverpool before an audience including leading surgeons, physicians, and pathologists, and again more recently in the presence of a certain distinguished physiologist. On these occasions they were listened to with the deepest interest and they evoked no adverse and depreciatory criticism whatever, even on the Edinburgh research funds. Lastly, let it not be forgotten that at times my findings and conclusions have an awkward habit of turning out to be true.

Feb. 5th, 1905. I am, Sirs, yours faithfully,

J. BEARD.

Io the Editors of THE LANCET.

SIRS, - In ThE LANCET of Jan. 14th, p. 120, under the heading "Local Irritation and Cancer," I suggested as an additional or alternative theory to cholesterine that glycogen in the same way leading to cell proliferation or alteration of type of division " may be due either to undue local deposition in the tissues or dependent on some nutritional disturbance in the liver or pancreas." Moreover, it had seemed to me, though I had not elsewhere seen it noted, that a similarity existed between this excess of glycogen in malignant growths and the excess of glycogen in foetal tissues which obtains from a very early period up to the fifth month when histological differentiation has largely advanced it begins to be deposited in the usual place, the liver, and its use to the economy becomes that to which it is put in the ordinary life of the animal (M. Foster).

In view of $\mathrm{my}$ belief, therefore, that in malignant disease the tissues have in some sense reverted to glycogenic tissue, either from over-production or non-conversion of glycogen, locally or generally, it may be of interest to point out that on Dec. 8th, 1904, I applied to Messrs. Parke, Davis, and Co. more especially to ascertain if taka-diastase had any amylolytic action on glycogen, suggesting at the same time pancreatic ferment. They replied that taka-diastase had little or no action but that the glycerine extract of pancreas had. Meanwhile as a result of experiments made by Mr. F. W. Gamble, pharmaceutical chemist, with various ferments, trypsin was found immediately and most effectually to break up glycogen. It is of interest, therefore, to me to find that Dr. J. Beard in his paper on the Cancer Problem ${ }^{l}$ independently corroborates the view expressed in the above extract from my letter that it is the pancreas which is at fault. Though his explanation of the use of tryosin in fotal life and presumably in malignant disease is different from mine it may interes him to learn that already on Jan. 19th, 1905, I had commenced to make trial of hypodermic injections of trypsin locally, together with the internal administration and outward application of pancreatic solution in a case of advanced recurrent cancer of the breast.

I am, Sirs, yours faithfully,

London, Feb. 6th, 1905 JOHN A. SHAW-MACKENZIE, M.D. Lond

\section{THE PUBLIC HEALTH LABORATORY OF MANCHESTER.}

To the Editors of THE LANCET.

SIRs,-Will you kindly allow me to rectify an error which has crept in in the account which you gave in your issue of Feb. 4th of the opening of the Public Health Laboratory in Manchester? Your informant states that there is a staff of 13 assistants, five students, one secretary, \&c., in the laboratory. This statement is obviously the result of some confusion; there are only three medical assistants (Dr. Sidebotham, Dr. Carver, and Dr. Sellers) engaged in reporting to sanitary authorities, in addition to which Dr. Sidebotham is also lecturer in practical bacteriology and Dr. Sellers assistant lecturer in comparative patho logy. Dr. G. Fowler has recently joined the staff as senior chemical assistant and Dr. Ramsden, who is University Fellow in Sanitary Chemistry, acts occasionally as junior assistant. No student or unqualified assistant takes part in public health investigations. There is also a technical assistant (Mr. Simons). The staff, including the secretary and myself, consists, therefore, of eight persons; only six, including myself, are qualified to undertake investigations for sanitary authorities. Several other gentlemen take part in the teaching of public health or other advanced students but they are not assistants in the department. Although the matter is not one of much importance I do not think it desirable to allow what might reasonably be considered a great exaggeration to come under my notice without attempting to rectify it.

Feb. 7th, 1905. I am, Sirs, yours faithfully

\section{THE PROGNOSIS OF ADOLESCENT INSANITY.}

To the Editors of THE LANCET.

SiRs,-In an annotation in THE LANCET of Feb. 4th p. 312, under the heading of "The Premature Dementia of Adolescents," you quote the opinion of Dr. Sérieux of Paris as to the curability of the "hebephrenic" and "katatonic" forms of "adolescent insanity" being only 1 in 10 . In my opinion-and this has been formed on a careful study of the disease from statistical and clinical facts--the statement is calculated to produce a very unduly pessimistic and painful general effect on your professional readers who have to treat such cases and on readers who have relatives suffering from "adolescent insanity." The facts, I maintain, do not warrant such an unfavourable view. In 1873 I segregated and described a large group of mental cases with similar symptoms and called it "arlolescent insanity." I subsequently gave an extensive series of clinical and statistical facts in support of my conclusion. The name and the description have been almost universally accepted by subsequent observers and authors, who, by the way, have seldom given me any credit for the induction. More recently German and American authors have adopted the term "dementia precox" to describe a sub-group comprised within adolescent insanity. Unfortunately no two of those authors mean the same thing by "dementia precox." Kraepelin has recently still further subdivided "dementia precox" into the divisions of "hebephrenic," "katatonic," and "paranoid." If any of your readers can form definite clinical pictures of those divisions ! from Kraepelin's descriptions and can then with confidence assort his patients under those groups I confess it is more than I have been able to do. I have always most strenuously contended that the term "dementia" should be reserved for incurable varieties of mental enfeeblement. This would save confusion, help to clarify our nomenclature, and, above all, would enable the general practising members of our profession to know better where they stand in using the word "dementia." I have no objection to the terms "hebephrenia" or "katatonia." I have much doubt about "paranoia," that fascinating and ever-changing rubbish heap. of delusion, obsession, hallucination, and over self-appreciation into which some authors cast 50 per cent. of the insanities, and others-Kraepelin lately-restrict to about 5 per cent. of all the cases. But to attach those terms to forms of "dementia" seems to me an instance of medical classification gone to the verge of absurdity and confusion.

As to the curability of adolescent insanity, I took 1796 consecutive cases of insanity and found that 320 of these were in the developmental ages between 14 and 25 years inclusive. Of those $320 \mathrm{I}$ had to deduct 90 as belonging to groups such as the epileptic and other forms. I found that the last five years, from 21 to 25 , produced most of the 230 remaining cases, or about 70 per cent. of them. That is the time when the higher brain centres attain their full and final development. Especially do the highest (motional, volitional, and moral faculties then blossom and seed. To provide the infinitely delicate brain vehicle for such fruit of mental evolution must try to the utmost the potentialities of the developmental nervous process. It is then evidently that hereditary mental defects chiefly show themselres and cause psychical breakdowns, just as in the earlier years the lesser developmental neuroses, such as chorea, epilepsy, hysteria, somnambulism, asthma, and megrim, are most apt to appear. $A$ careful study and summarising of the symptoms in the 230 